\title{
Research on Inheritance of Traditional Handicrafts of Tin Embroidery Costume in Jianhe
}

\author{
Ren Shan \\ Faculty of Humanities and Arts, Macau University of Science and Technology \\ Macau, China \\ College of Design, Beijing Normal University Zhuhai \\ Zhuhai, Guangdong, China \\ renshan0211@126.com
}

\begin{abstract}
Tin embroidery belongs to Miao embroidery, which is quite different from other types of embroidery not only in Miao areas but also in the whole world. Traditional handicraft is the essence of ethnic culture. With the development of economic globalization and the changes of people's lifestyles, the survival and inheritance of national traditional handicraft has become a knotty problem. Based on field study, this paper mainly analyzes the present situation of the traditional handicraft of tin embroidery costume in Jianhe Miao region, points out the problems existing in the process of protection and inheritance, and put forward better protection and innovation strategy, so as to let more people know about minority costume, mobilize people protect traditional handicraft, explore new ways to validly inherit and protect traditional tin embroidery costume handicraft in Jianhe.
\end{abstract}

Keywords-Miao; Miao embroidery; Tin embroidery; Traditional handicraft; Inheritance; Innovation

\section{INTRODUCTION}

Miao embroidery has the function of inheriting history and culture, which is mainly reflected in the patterns of embroidery. Almost every embroidery pattern has a history or legend, which deeply contains the ethnic culture, is the expression of national emotion, and is the display of Miao history and life.

The theme of Miao embroidery has nothing to do with the real life scene. It is the expression of consciousness at the spiritual level, the concept of ethnic survival, the worldview and the understanding of everything in the world. Including flowers, birds, insects, fish, Miao female embroiders apply the abstract art, bold exaggerated deformation on the embroidery through their careful observations and experiences in order to show the creator's aesthetic feeling and life ideal.

Miao embroidery is not subject to the constraints of natural form and time and space. Each picture is completely free from the imagination and emotion of the creator. It can make peach flowers; plum flowers and chrysanthemums coexist at the same embroidery. It can make all kinds of creatures in the world coexist in harmony [1].

With economic globalization and the integration of global culture, the trend of industrial mechanization replacing traditional handicrafts is irresistible. Traditional folk handicrafts are inevitably impacted by modern development, and many handicrafts are failing to be handed down from past generations or completely disappear. Traditional handicrafts in minority re- gion are not only a means to provide material products, but also a crystallization and carrier of excellent ethnic history and culture. Protecting ethnic traditional handicraft is an important manifestation of respecting ethnic traditional culture and a way to display cultural confidence. Therefore, it is very necessary to take effective measures to carry on the inheritance of the precious handicraft of Miao tin embroidery costume in Jianhe area.

\section{TYPES AND CHARACTERISTICS OF TRADITIONAL HANDICRAFT OF MIAO TIN EMBROIDERY COSTUMES}

For more than 600 years, Jianhe Miao tin embroidery has been passed down from generation to generation by groups of inheritors. For a nation without written records of history, costume has become the visible and tangible records in Miao's historical inheritance and cultural communication. It is a unique "history book on the body", which tells the joys and sorrows of the development of this nation [2].

Costume is the carrier of Miao culture, in which Miao embroidery occupies an important position. The ancestors of Miao had an extreme pursuit of embroidery technology, which made Miao embroidery have the characteristics that other nationalities cannot copy no matter in technology, content or connotation. There is no exact number of Miao embroidery species, however, no unified statements exist. To be sure, there are at least more than 20 kinds, respectively, piping, holding needle embroider, braid embroidery, crepe, short needle embroidery, seeds, overlapping embroidery (or called barbola, heap ling embroidery), dish nail embroidery, flat embroidery, lace embroidery, thread embroidery), tin embroidery, mat, broken line embroidery, straight needle embroidery, weaving embroidery, patch embroidery, bumps, plait embroidery, embroidery, horsetail embroidery, etc.

On account of its special materials and complicatedly exquisite craftsmanship, Miao tin-embroidered costume creates a school of its own in China's embroidery and was listed in the first national nonmaterial cultural heritage list in 2006. Miao tin embroidery is developed and extended on the basis of weaving and cross-stitch. As one of the most unique costumes in Jianhe, compared with other Miao costumes, its colors are few and simple, its design is abstract and concise, its manufacturing process is complex, whereas its costume has a strong visual impact and contains high artistic value [3]. This paper 
focuses on the hand-made fabrics and manufacturing process of tin-embroidered costumes.

The main features of the traditional handicraft of the Miao tin-embroidered costumes in Jianhe are as follows: (1) Miao people in Jianhe area obtain materials from local sources. For example, all the materials such as indigo and rattan which are used in hand-made bright fabrics dyeing are without exception from local sources, and these materials are from nature without any ecological pollution. (2) Its process flow is fixed. After a long period of historical accumulation, ethnic traditional handicraft has passed on from generation to generation to inherit, and its process flow is relatively fixed. (3) Oral teaching is the mode of conservation and inheritance. The protection methods of traditional ethnic handicraft are passed on from the inside to the outside, and there are also the teacher-apprentice methods of oral communication. (4) The practical functions are strong. The traditional handicraft of ethnic minorities is related to the life of local residents, which is the creative production of people in labor. Therefore, it has strong practicability, such as the clothes made of bright cloth, the blue basket made of vines and so on. (5) There exist regional diversities. The same kind of process varies from place to place, and there are also some differences in materials and processes. For example, different villages in Jianhe area have different forms, patterns and styles of tin embroidery costumes.

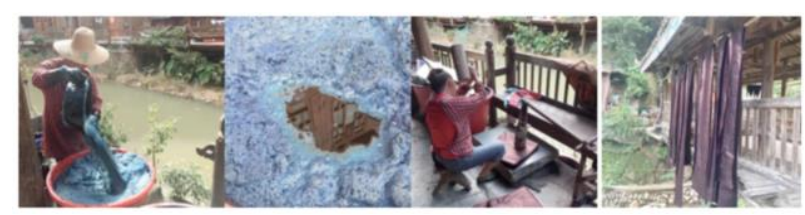

Fig. 1 Process of Making Traditional bright cloth

\section{PROBLEMS AND OPPORTUNITIES IN THE INHERITANCE AND INNOVATION OF HANDICRAFTS}

With the development of economy and the improvement of people's living standard, traditional handicraft of Miao costume in Jianhe area is facing challenges of being lost or disappearing. The author has conducted field study and investigation in Mindong and Guanmo villages in Jianhe where is located in Qiandongnan Miao and Dong Autonomous Prefecture in Guizhou province [4]. Through field visits and observation, it is found that traditional tin embroidery costumes are already their daily wears, except certain number of elderly over the age of 50 still wear the traditional hand-dyed costumes, the majority of people wear them only when there are important festivals. Most of people, no matter early youth, youngster, middle-aged or elderly, are wearing modern clothes the same as Han people. Fewer and fewer people weave clothes or fabrics in the villages and marketable woven fabrics become their first choice. Through field investigation and analysis of Jianhe, the author thinks that the traditional handicrafts, including dyeing and weaving and other traditional handicrafts, which are involved in the Miao tin embroidery costumes are faced with the problem of no inheritor. After field visits and interviews, the reasons for the current situation are concluded as follows:
Industrial production mode gradually replaces traditional craft production. With the development of industrial production, the automatic production mode of mechanization gradually replaces the traditional manual manufacturing, which is the inevitable trend of social development. Products under mechanization production are with high output, low price, numerous varieties and are favored by consumers, which greatly improve the Jianhe Miao people's living conditions. However, at the same time, to a certain extent, it is a shock to the local traditional handicraft products. And it also led that less and less people who would like learn ethnic traditional handicrafts. Combined with the clothes made by chemical fiber materials, to complete a piece of tin embroidered costume takes too long to weave, dye and embroidery. The consumption of time and energy is relatively more, yet chemical fiber clothes have more choice and low-price, as a result, traditional costumes are gradually replaced.
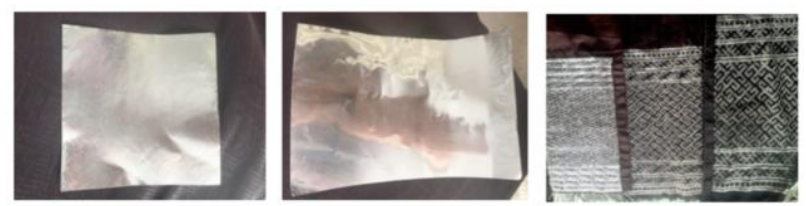

Fig. 2 Materials used for tin embroidery of jianhe miao nationality (followed by tin sheet, antimony sheet and embroidery sheet)

As economy develops and society is in progress, people's lifestyle and life concepts have changed. Most of residents from Jianhe have already discard wearing traditional costumes except major festivals. This phenomenon is most pronounced among young groups. Because of out-migration for work or study, they are in pursuit of new, modern and good-looking wears instead of traditional ones. Those external cultural influences bring huge changes to local ethnic culture.

Traditional handmade products are inefficiency. Nowadays, fewer and fewer people in Jianhe area use traditional manual skills to make products. Handmade products often take a long time to complete. Nowadays, Miao people continue to make costumes by hand, such as dyeing cloth and embroidering, mainly for major festivals and holidays.
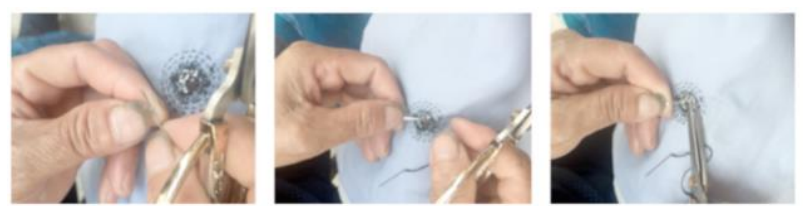

Fig. 3 Steps for embedding tin bars

There are certain limitations in traditional handmade products. Due to the remoteness of Jian area and no written records, traditional crafts and skills hand down from generation to generation. Such as bright cloth, tin embroidery techniques, brocade technique are demonstrated transmitted to offspring from the old man through the dictation. Those skills preserve their traditional way, in the meanwhile, are lack of modern design and innovation. What is more, the process is relatively compli- 
cated, although the traditional design and color to a great extent embodies Miao culture and characteristics, it is hard to adapt to the modern aesthetic demand. As a result, handicraft inheritance not only need to protect the existing craftsmanship, at the same time also need to be done on the basis of innovation. Only in this way can the ethnic culture and elements meet the needs of the development of modern society.

Traditional handicrafts are lack of effective market guidance and commercial channels. Their traditional living way is one in which men plowed the fields and women wove cloth. Weaving, dyeing and making clothes by hand are all for selfsufficiency and meet the needs of family members. Nowadays, the rich variety of mechanized products can fully meet the needs of family members, which makes traditional manufacture gradually limited to develop. This kind of handicraft also lacks effective market guidance and commercial channels. Because of no certain commercial channels, this kind of handwork method will gradually be forgotten.

Our country promotes "craftsman spirit" and cultural confidence to promote the protection of handicrafts. The state vigorously advocates the spirit of craftsmanship and provides protection and inheritance of folk handicrafts. In such an environment, it is of great help for the protection, inheritance and innovation of handicrafts [5].

Economic globalization and the development of global cultural integration promote the development of handicrafts. Along with the development of economic globalization, the cultural fusion between different regions, different nationalities made national handicraft culture go abroad. In recent years, we can find numerous Chinese ethnic elements, such as embroidery, tie-dye batiks patterns in Guizhou, paper cutting process, manual printing and dyeing techniques, etc., are applied in many international fashion shows. Many Chinese designers blend in Chinese elements of modern fashion design, many foreign brand designers have also come to China to look for Chinese elements, combining the traditional Chinese ethnic art elements with modern design.

The change of the mass consumption has led more and more people to pay attention to handicrafts. Industrial development has enriched people's material life, but as people for the pursuit of spiritual life and changes of lifestyle, more and more consumers pay attention to beauty-appreciation and comfortable-wearing. Natural environmental protection, primitive materials and environment-friendly fabrics, style individuation, and comfortable-wearing are their consumption needs. Changes of the consumption psychology and consumption way offer a broad space for traditional arts and crafts especially apparel crafts heritage development [6].

\section{MEASURES FOR INHERITANCE AND INNOVATIVE DEVELOPMENT OF TIN EMBROIDERY COSTUMES}

We should establish the awareness of inheriting and protecting traditional handicrafts. Traditional handicraft reflects the historical development and cultural connotation of a region. It needs to be passed on from generation to generation to better understand and inherit. In addition, the traditional culture of ethnic minorities has boundless cultural value. Therefore, to establish the awareness of inheriting and protecting traditional handicrafts not only requires local people, but also requires people to form a sense of cognition, understanding, protection and inheritance.

We should improve the inheritance and protection policies of traditional handicrafts and carry out ecological museum.

The ecological museum is a museum that preserves and introduces the living condition of human groups in the original address, social and cultural conditions. Ecological museum breaks through the concept of traditional museum collection and architecture and pays attention to the protection and development of national culture [7]. It does not freeze culture, but expands the scope of protection to the community or village in the region where it is located, making every villager a master of the inheritance and development of cultural heritage. For example, Dong ecology museum, located in the Tangan village of Zhaoxing, is a good way to protect and inherit Dong culture. This museum is built and protected by China and Norway. The ecological museum is located in the community and environment where cultural heritage should be protected and preserved as it is. Therefore, the inheritance of Miao costume and handicraft in Jianhe can also be protected by referring to this model, which not only protects the traditional handicraft completely, but also serves as the cultural name card for the region to be displayed to the outside world, so as to expand and attract more people to travel, study and protect it [8].

Traditional handicraft enters the classroom, develops the teaching research popularization. Classroom teaching is the best way to pass on the crafts. Nowadays, more and more parents and schools attach importance to art education and manual education and introduce handicraft into schools to cultivate children's interests in various aspects. In colleges and universities, handicraft not only serves as the student interest study, but also provides various methods for the related design.

The innovative development system advocates the integration of traditional handicraft and modern design elements. Traditional arts and crafts need to be protected and inherited. More important is on the basis of the protection and inheritance of combining modern design elements and methods for comprehensive application. Handicraft embodies profound historical culture and traditional techniques, the fusion of traditional and modern value is deeper, this has a great effect to the development of the innovation of the traditional arts and crafts [9]. The modernization of traditional handicraft design, in fact, has continued the form and craft of traditional handicraft and expanded the scope and form of traditional handicraft, such as adding some new categories, new forms, new styles and new materials. Therefore, only by unceasingly exploring the cultur- 
al resources in the traditional handicraft, developing and innovating products with the characteristics of the present, and constantly building the national craft brand, can the traditional handicraft of the nationality be better developed and protected. For example, we will carry out various kinds of ethnic cultural activities, costume design competitions and handicraft competitions to encourage more people, especially young people, to love learning, protection, inheritance and innovation of excellent traditional culture.

Relying on information technology is one way to export manual skills and culture. Craftsmanship, such as bright cloth, tin embroidery, blue prints need to let more people know under effective promotion. So the handmade arts and culture can be more popular. Through the digital museum of arts and crafts and VR virtual display technology, not only can Jian Miao handicrafts be spread to the world, more national culture for the masses in the region can be known. In the future, there will be more and more people who like and love ethnic culture and Miao tin embroidery. Each one of them will be a disseminator of traditional culture and costumes to let national wealth be known by the world.

\section{CONCLUSION}

Jianhe Miao tin embroidery, like many valuable intangible cultural heritage of ethnic minorities, is facing unprecedented challenges and is in danger of disappearing in the face of the strong impact of diversified culture in modern society. As is known to all, costume is an important representation of human aesthetic pursuit. The colors, patterns and crafts of tin embroidery costumes are the most basic elements to carry their ethnic culture. Whether it is abstract patterns or specific composition forms, whether it is tin embroidery or traditional dyeing and weaving, it is the best protection and inheritance for national culture and national craft.

\section{ACKNOWLEDGMENT}

Quality project of Guangdong province "School-school collaborative international education model and mechanism innovation pilot area" (NO.2014307); Quality project of Beijing Normal University Zhuhai "Specialty training of applied talents in Fashion and Accessories Design" (NO.201540); Project of Beijing Normal University Zhuhai “ Teacher research capacity promotion program"(NO.201850008).

\section{REFERENCES}

[1] PENG Yang, Symbols and symbols: research on patterns of miao nationality red embroidery and tin embroidery in jianhe county, Master's thesis of guizhou university, 2016, pp. 17-23.

[2] HUANG Zhulan, Enlightenment of Guizhou Miao Traditional tin Embroidery on Modern Clothing Decoration Process, Guizhou Ethnic Studies, 2013, pp.59-60.

[3] PENG Yong, A probe into the aesthetics of tin embroidery art of miao nationality, National art, 2012, pp.126-127.

[4] LIU Chunyu, ZHEN Yong, Field investigation on the tin embroidery technology and patterns in jianhe, guizhou, Chinese culture BBS, 2016, pp.111-114.

[5] YANG Zhuhui, Research on Dong Culture, Central university for nationalities press, p. 35, 2014.

[6] ZHENG bo, ZOU yu, The practice and exploration of the branding of traditional folk handicraft -- taking the silver decoration brand of guizhou jincai ethnic culture research and development co., LTD as an example, Journal of original ecological ethnic culture, 2014,20.

[7] MA Wenjing, Discussion on the inheritance and development of traditional handicrafts in ethnic areas, Guizhou ethnic studies, 2009, pp. 165-168.

[8] LI jiayi, A study on the innovation of tourist crafts with the integration of ethnic cultural elements and modern design concepts, Guizhou ethnic studies, 2015, pp. 166-168.

[9] SUO Xiaoxia, Research on inheritance and development of miao costume handicraft in guizhou from the perspective of intangible cultural heritage, Master's thesis of guizhou university of finance and economics, 2014, pp. 5-8. 